\title{
Importance of Training Students' Workforce in the Applied Technology Universities
}

\author{
Zongcheng Miao ${ }^{\mathrm{a}}$ and Yongming Zhang ${ }^{\mathrm{b}}$ \\ Xijing University, Xi'an, Shaanxi Province, 710123, PR China \\ amiaozongcheng@163.com, ${ }^{\mathrm{b}}$ zhangyongming@xijing.edu.cn
}

Keywords: College student; Workforce; Applied technology universities; Talent training

\begin{abstract}
With the development of market economy of China, the workforce of employee has been required more strictly. For this reason, the primary mission of university should be combined with the actual situation of social development, talent market and employing unit to improve the professional ability of students. University should focus on training the students' ability of service, management and technology. In this paper, the necessity is point out about enhancing the workforce of students for a modern university, and the concrete scheme is discussed of training the work force of university students based on analysis present situation.
\end{abstract}

\section{The Necessity of Enhancing Workforce of University Students}

The Workforce of University Students is Urgent Requirement for Development of Economy Society. Applied technology of the university is related to economic development according to the Chinese education system [1-3]. The applied technical students trained by university through their own education happen to be the strong backing for talents demand of the rapid economic and social development [4]. The development of market economy needs the students with high quality and high technical ability, because the current situation of China is in the primary stage of socialism. The lack of high skilled personnel will lead to the bottleneck period in the rapid development of social economy, and technology is not able to change into productive forces $[5,6]$.

Currently, comprehensive national strength competition, in fact, is the talent competition. Talent reserve has become the necessary protection of social and economic development [7]. Talent reserve is the important foundation for science and technology development and promotion. Therefore, the cultivation and education of the college students of applied technology university should not only focus on the theory of the inculcation of knowledge, but pay attention to enlarge college students' experience, improve the students' workforce, enhance the social experience of students [8]. Accordingly, it is very important for applied technology university to improve students workforce in the teaching process with the market guide, it should be to training students' practical ability as the center.

Students need to Develop Their Professional Ability by University. First, students after graduation will be faced with the problem of employment, therefore, students themselves need to improve their workforce, strengthen their comprehensive strength. They are conducive to solving the employment problem in the future, to enhance its independence [9].

Secondly, the training professional ability of applied technology university to students will help students understand the whole its advantages, improve their comprehensive ability in accordance with their own advantages to avoid the blindness in the learning process. It will help students reduce the waste of time strengthen the purpose of learning.

Thirdly, training students own workforce is the cornerstone of realizing students' ideals and values. Training and exercise workforce of applied technology university in vocational skills education for students will guide the students' inner to enhance the confidence of students learning and life, help students to make full use of their potential, enhance their own value in the society, create a piece to belong to own sky.

Training Students' Workforce is the need of Constructing the Complete and Systematic Education System. With the development of economic and social, the teaching scale of university 
has got enlarged continuously, the number of graduates have increased each year [10]. Therefore, the problem of graduation meaning unemployment increases serious, this will bring great challenges to higher education. The survey shows that the reason of unemployment of university students lies in its low workforce. Therefore, in order to meet the needs of the development of the times under the new situation, corresponding adjustment has been made on the aspects of teaching objectives, teaching plan and syllabus in Chinese universities. Increasing workforce training in the teaching process is very important to enhance the technology application of the students, to improve education system in universities.

\section{Development Status of Training Students' Workforce in Universities}

Traditional Educational Ideas. At present, Chinese universities are all focus on the aspects of enrollment and employment, especially they simply think that students recruit came in, and then graduated from is the whole process of education under the background of the long-term traditional education ideas of taking examination as center. Students' workforce to win office has been largely ignored, and the mining potential of the students themselves are lack of high concern, fundamentally ignored the workforce of students of education and culture.

Unreasonable Curriculum Setting. Under the influence of the traditional education theory of value theory more than practice, the scientific and reasonable professional curriculum system has not been formed in the Chinese higher education. Reasonable opening of professional curriculum is prerequisite to train applied talents. If professional curriculums in universities are lack, the training enhancing of students' workforce is a pig to fly in the sky.

Formalization of Workforce Training. The core part of the training of students' workforce is practice teaching in applied technology universities. However, the enhancing of students' workforce has been affected by a series of problems existing in current teaching, such as the practical lack of teachers, teaching methods, a single, teaching evaluation system is not perfect, teaching quality standard non-standard, resulting in difficult to protect the effect of the practice teaching, practice teaching from content, ends with the form.

\section{Concrete Countermeasures to Train Students' Workforce in the Applied Technology Universities}

Teaching Materials Pay Attention to Update the Contents of Training Students' Workforce. The teaching materials of the applied technology universities must conform to the requirements of the development of the times, and must make reasonable scientific adjustment according to the actual situation of social development. Teaching content should emphasize practical application of knowledge, improve the students' workforce, reflect important value of application technology talents in the society, and especially meet the trend of the development of the times. Teaching content should closely link the social practice and professional teaching process together, and establish solid foundation of knowledge, practical application of knowledge deep, higher vocational capability of technical application type teaching material system. On the other hand, according to the rule of development of each discipline, teaching content should be strengthened embodying in the times. Subject content in various parts should be combined to guarantee the uniformity and system of teaching material contents.

Moreover, universities should pay attention to teach students in accordance with their aptitude, to keep certain targeted on students' vocational ability training, to get rid of the past blindly passive mode of teaching material. Teaching materials should be focused to meet the requirements of each subject's own uniqueness and the teaching effect. In understanding students' actual situation of foundation, the better the material in the foundation, the important and difficult points should be highlighted, in order to promote the students to improve their own professional ability of enthusiasm and initiative.

Strengthen the Teachers' Construction and Improve the Professional Level of Teachers. Training teachers' ability is premise and foundation of training students' professional ability. 
Therefore, applied technology university should pay attention to improve the teacher's professional ability, to enhance the ability of teachers training. At the same time, teachers should fully understand social development and the enterprise with the actual needs, and constantly update education concept to improve the professional teaching ability and quality as a whole. In addition, teachers should base on the teaching objectives to update teaching methods, and to cultivate professional applied talents with high skills. Moreover, universities can make co-operation through hiring professional teachers from enterprise to strengthen the teachers' team, to construct combination of full-time and part-time double teacher type team, to give full play to the education, science and technology, and network channels. Universities should provide good hardware facilities and teaching environment for teachers to carry out practice teaching. The talent ability, knowledge and competence development should be reflected to the applied technical talents training, and improved the teaching effect.

Improve the Applied Technology Teaching Evaluation System. At present, with the rapid development of new situation of economic and social, applied technology of teaching should conform to the development trend of the times, both with respect to the individual differences of students, and with the development of social practice, should establish and improve a set of scientific and reasonable application of technology teaching evaluation system. Firstly, comprehensive evaluation, not only the midterm and final exam scores as the only evaluation criteria, should be established, and the regular assignments, classroom performance, experimental operation and other forms of assessment should be bring into the assessment system. Secondly, task-based assessment model should be carried out. In particular time, it should let students to complete a specific task, and the tasks given to open the answer. The teacher can evaluate the ability according to the students to complete the task. Finally, bundling type assessment methods should be used. It should separate students into many groups, select randomly a student to evaluate score. The group assessment scores refer to the student's performance as the other members. This evaluation system should help to improve the solidarity between the students, to enhance their sense of team.

\section{References}

[1] S. Kennedy, A. Kenny and P. O'Meara. Nurse Education Today, Vol, 35(2015), p. 1037-1043.

[2] S. Scott, J. Karen, E. Cleese and S. Shana. Academic Medicine, Vol, 88(2013), p. 1904.

[3] C. Wilson, C. Keane, H. Houlton. Limnology and Oceanography Bulletin, Vol, 23(2014), p. 30.

[4] M. E. Diane and J. W. Pamela. Early Childhood Research Quarterly, Vol, 16(2010), p. 285.

[5] C. Matson, A. Davis, J. Epling. Annals of Family Medicine, Vol, 13(2015), p. 494.

[6] N. Choudhurya, A. McIntoshb. International Journal of Hospitality Management, Vol, 32(2013), p. 261.

[7] E. Comeaux. Journal of Student Affairs Research \& Practice, Vol, 50(2013), p. 37.

[8] J. James and J. D. Kevin. New Directions for Community Colleges, Vol, 136 (2006), p. 53.

[9] E. A. Ann. Higher Education: Handbook of Theory and Research, Vol, 73 (2002), p. 94.

[10]J. Rojewski. Journal of Vocational Education Research, Vol, 29(2002), p. 7. 